\title{
Reconceiving International History
}

\section{Citation}

Erez Manela. 2009. "Reconceiving International History." Reviews in American History 37 (1): 6977. doi:10.1353/rah.0.0070. http://dx.doi.org/10.1353/rah.0.0070.

\section{Published Version}

doi:10.1353/rah.0.0070

\section{Permanent link}

http://nrs.harvard.edu/urn-3:HUL.InstRepos:25500673

\section{Terms of Use}

This article was downloaded from Harvard University's DASH repository, and is made available under the terms and conditions applicable to Other Posted Material, as set forth at http:// nrs.harvard.edu/urn-3:HUL.InstRepos:dash.current.terms-of-use\#LAA

\section{Share Your Story}

The Harvard community has made this article openly available.

Please share how this access benefits you. Submit a story.

Accessibility 


\title{
RECONCEIVING INTERNATIONAL HISTORY
}

\author{
Erez Manela
}

Matthew Connelly. Fatal Misconception: The Struggle to Control World Population. Cambridge, Mass.: Harvard University Press. 2008. xiv + 521 pp. Illustrations, notes, and index. $\$ 35.00$.

Few who read Matthew Connelly's important new book will forget the opening scene. It is June 18, 1877, and the trial of freethinker, socialist, and women's rights activist Annie Besant had just begun at the Queen's Bench Court in London. Besant and her associate, Charles Bradlaugh, were on trial for circulating an "obscene pamphlet" by the American birth control advocate Charles Knowlton, which included explicit descriptions of sexual anatomy and contraceptive techniques such as condoms, sponges, douches, and withdrawal. Rising in her own defense, the twenty-nine-year-old Besant, "beautiful and brilliant," explained why she had done it. Without birth control, she warned, England would become as overpopulated as China and suffer the same fate: war, famine, and disease (pp. 18-9). That very same year, Connelly notes, famine struck in both India and China and nativist riots against Chinese immigrants broke out in California.

This startling juxtaposition of events forms the starting point of Connelly's original and wide-ranging exploration of the history of the movement to control world population. This book joins a small but growing body of literature that is putting to rest the common perception that work on the history of international organizations and NGOs is bound to be a soporific alphabet soup full of indecipherable acronyms and mind-numbing dissections of institutional mission statements. Connelly has mined a vast array of NGO and international organization archives, including those of the International Planned Parenthood Federation (IPPF), the Rockefeller and Ford foundations, and the National Conference of Catholic Bishops, as well as a plethora of private papers, to distill a story full of dramatic encounters, striking discoveries, intriguing interpretations, and global historical significance. Fatal Misconception is not the first work to focus on the role of non-state actors in the history of international society. ${ }^{1}$ But Connelly's methodological sophistication, narrative skill, and provocative arguments will no doubt energize the field and serve to encourage further work in it. 
The narrative begins in the late nineteenth century, when ruling elites in emerging nation-states in Europe and elsewhere regularly thought of populations in the aggregate as yet another resource to be managed and utilized by the state, and when scientists, officials, and intellectuals worked to measure and control both the quality and quantity of that resource. Connelly defines "population control" broadly, as encompassing not only the interrelated concerns with the quality and quantity of populations but also with its movement, and his opening chapters weave a wide-ranging narrative involving anti-immigration movements, social Darwinism, scientific racism, phrenology, and the rise and influence of such concepts as the "Yellow Peril", Lebensraum, and "race suicide." Connelly's main task, he writes, "is to discover, specifically, how such protean concepts evolve into norms, practices, and institutions that empower people or manipulate them, enrich or impoverish, give life or take it away, sometimes all at the same time" (p. 8). The demographic devastation of World War I intensified the fears of the West's demographic decline, and in the ensuing decade Lothrop Stoddard's warnings about "the rising tide of color" echoed even as Margaret Sanger's advocacy of "birth control" —a term she coined in 1914-was gaining momentum. This was the age of eugenics, and Connelly reminds us that the term, associated today with pseudoscience and the Holocaust, was in its day often viewed as a progressive cause and supported by figures ranging from W. E. B. Du Bois to John Maynard Keynes. This period also saw the first international meetings on population, where ideas were debated, plans hatched, and connections made. For Connelly, these gatherings were pivotal in the development and operation of the movements to control world population. His account of the first such meeting, the World Population Conference convened in Geneva in 1927 by the International Labor Organization, introduces several of the story's main themes. One is the marginalization of women, both as activists and as "targets," by paternalistic, careerist male "experts" who populated the positions of power in academia and private foundations. The second is the tensions, disagreements, and rivalries-personal, ideological, and institutional — that dogged the movement throughout its history, and made the 1927 conference a "massive setback" that failed to mobilize an international movement for population control (p. 74).

Despite the failure to mobilize internationally, however, ideas about population control continued to develop. By the 1940s, family planning had become an important component in the package of social reforms that would create the postwar welfare state, and influential advocates such as Gunnar and Alva Myrdal emphasized the combination of welfare, education, and access to contraception as the way to better the lives of children and improve society at all levels. But as the cause of population control—or "family planning," as it was becoming known in polite society-gathered speed, it also faced powerful opponents across continents and cultures. The Catholic Church 
was first and foremost among them; not least, its influence on domestic U.S. politics convinced Franklin D. Roosevelt to keep the cause of family planning at arm's length. But Mahatma Gandhi, too, was a firm opponent, telling Sanger when she came to see him that contraception was hedonism and that, in his view, only abstinence (and perhaps rhythm) was an acceptable method of regulating fertility.

Though the first three chapters of the book, which take the story down to the end of the Second World War, make for fascinating reading, they largely function as an extended introduction to the book's central concern, the story of the massive family planning programs of the postwar world. While Connelly has crafted a vivid, multi-faceted narrative on the earlier period, much of what he covers, from anti-immigration movements to eugenics to the career of Margaret Sanger, will generally be familiar to American historians of the period. Connelly's research on the postwar period, on the other hand, has plowed territory into which few historians have yet ventured, and it is the story of this period that stands at the analytical, narrative, and dramatic core of the book.

Partly, this focus is dictated by the numbers. It is after 1945, after all, that the exponential population growth in the non-European world, long predicted with dread by Stoddard and his ilk, actually gained momentum, and the rising fear of such "differential fertility" among Western leaders and intellectuals exacerbated the crises of colonialism in the immediate postwar years. Even as an unprecedented number of censuses taken around the world allowed UN demographers to issue, for the first time, credible estimates of "world population," the French demographer Alfred Sauvy argued that without a world government the very notion of a single "world population" was meaningless. Instead, Sauvy proposed, there were in fact three worlds: the capitalist and the communist, which were headed toward convergence in modernity, and a "third world," caught in a "cycle of misery" (p. 153). Though Sauvy called for assistance to the Third World, his vision, Connelly notes, was driven by the fear that accepting the idea of a "world population" would legitimize demands for unfettered migration and the global redistribution of land and resources. The concept of the Third World, then, was forged to fence non-Europeans populations within their own regions.

Even with evidence of the runaway growth of the world's population, however, progress for those who wanted to control it remained difficult. In the new international institutions established in the war's wake, One World advocates such as Julian Huxley of UNESCO and John Boyd Orr of the Food and Agriculture Organization called for a global population policy. But they were rebuffed by an unlikely coalition of member states, including many Catholic, communist, and Arab countries, as well as the U.S. government, which feared critics at home and abroad. Dwight Eisenhower, for example, 
privately worried about population growth in the Third World, but he would not touch the issue publicly for fear of attracting criticism from Catholics and other domestic opponents of contraception and accusations of racial genocide from Third World leaders whom he hoped to tempt into the American camp in the Cold War.

Blocked within the UN system, population controllers regrouped outside it. One of Connelly's achievements in this book is his reconstruction of the global postwar network of population controllers, carefully uncovering and tracing connections that ran between governments, private foundations, and the academy, and sketching out the sinews of power, money, and prestige that held the system together. The founding event of this "population establishment" — an evocative term-was an invitation-only conference convened by the philanthropist John D. Rockefeller, III, in Colonial Williamsburg in 1952. This conference brought together leading academic demographers with the Rockefeller Foundation's money men and gave birth to the Population Council, which set out to expand and globalize the network by funding the training of demographers worldwide, many under Frank Notestein's Office of Population Research at Princeton. Another central node in the network, the International Planned Parenthood Federation, was established in London that same year to coordinate activities across national affiliates.

If the core of the population establishment consisted of wealthy foundations and prominent academics, Connelly also excavates its broad penumbra, populated by a gallery of curious characters. There was Dixie Cup baron Hugh Moore, who devoted his fortune to reducing the world's poor population to ward off the dangers of communism. Household products heir Clarence Gamble fancied himself a birth control entrepreneur who wanted to develop cheap contraceptives - at one point he insisted on experimenting with sponges dipped in saltwater - and established his own outfit, the Pathfinder Fund, when mainstream organizations refused to give him control. And, with a subject as controversial as birth control, some of the most transformational developments were bound to occur outside the "establishment." The birth control pill itself emerged by the early 1960s as a result of collaboration between International Harvester heiress Katharine McCormick and biologist Gregory Pincus, who co-founded and worked at the Worcester Foundation for Experimental Biology after being denied tenure at Harvard.

The prominence of private money, most of it from U.S. sources, in the population establishment reflected the continued reluctance of major Western governments to support family planning programs oversea. But establishment experts, richly funded by Rockefeller and Ford money and ensconced at top universities, committees, and institutes, still managed to make headway with Third World leaders who viewed family planning as a central component of crash modernization programs. Pakistan's authoritarian president Ayub 
Khan, for example, took keenly to the IUDs shown to him by Notestein, and by the early 1960s the devices were already widely in use there, as well as under the modernizing, authoritarian regimes in Taiwan and South Korea. In populous India, family planning programs had been part of the government's development vision since the first five-year plan in 1952, and by the early 1960s they stood "at the very center of planned development," with mobile vasectomy camps performing 158,000 sterilizations in 1962 (p. 192). Family planning programs received a further boost in 1966 when Indira Gandhi, a strong proponent, became prime minister.

By the mid-1960s, even the United States government was joining the bandwagon. Lyndon Johnson saw support for family planning programs as a crucial part of his global war on poverty, and under his administration large sums of foreign aid began to flow to them. Much of the money was funneled through USAID's population program, whose flamboyant chief, Reimert Ravenholt, took to such stunts as distributing condoms with his business card printed on the wrapper. Concern about world population growth reached fever pitch within the U.S. public as Paul Ehrlich's 1968 bestseller The Population Bomb popularized apocalyptic demographic scenarios, and a rising environmentalist movement emphasized the dangers that "exploding" populations posed for the health of the planet.

Even in the heyday of the population control movement, however, opposition remained broad and powerful. The Catholic Church, as staunch an opponent as ever, made its influence felt both in international organizations and within the United States, and the Soviet bloc countries also generally opposed UN support for family planning programs in the Third World, perhaps viewing them as a capitalist design to shrink the size of the global proletariat. And while some postcolonial leaders, particularly in densely populated countries such as India, Pakistan, Indonesia, and the Philippines, were enthusiastic, others, including many in Latin America, the Middle East, and Africa, remained resistant, some even accusing Western family planners of plotting racial genocide. Within the United States, too, representatives of the oppressed such as the Black Panthers, the Nation of Islam, and labor leader Cesar Chavez took similarly dim views of domestic programs that encouraged contraceptive use in poor and minority communities.

The struggle between supporters and opponents came to an epic climax at the 1974 World Population Conference in Bucharest. With a keen eye for irony, Connelly points out that Romania, the host country, was at the time the only country in the world with an explicit, target bound policy for increasing its population, and that the conference chair was a father of six. By then, USAID had become a major supporter of family planning programs around the world, with funds often laundered through international organizations and NGOs. But foreign donors could not always control the programs that they helped 
fund. National governments, though happy to accept international aid, insisted on retaining control, and sometimes they went farther than even the most gung ho NGO could countenance. In 1971, as a Gujarat official boasted that the sterilization of 223,060 people in just sixty days set "a new world record," the IPPF reported that India was "going wild on vasectomy and tubectomy camps" and advised that support for the program be halted (pp. 292-3).

Such excesses emboldened the opposition and helped turn the Bucharest conference into the "Waterloo of the population control movement" (p. 316). In addition to the usual sources of opposition, feminists now also rose to challenge the entrenched, male-dominated population establishment, arguing that existing family planning programs marginalized women and, if they were to continue at all, they would have to become only one part of a broad development agenda that put the empowerment and welfare of women first. Indeed, for Connelly it was the rise of women-as activists within the movement and as subjects who had rights rather than objects that had to be controlled-that ultimately redeemed the family planning movement as a whole.

In India, increasingly coercive family planning initiatives culminated during the Emergency Period of 1975-77 when Sanjay Gandhi, Indira's dissolute younger son, led a "modernizing" assault on the urban poor that combined forced sterilization with slum clearance. For Connelly Sanjay, a violent, corrupt man who was even said to have slapped his own mother on one occasion, is the perfect metaphor for the population control movement as a whole: "A man with no formal title who answered to no one-not even his motherwas just the kind of person to lead a population control campaign" (p. 318). And the shocking defeat of Gandhi's Indian National Congress in the 1977 elections that came in the wake of Sanjay's campaign was in turn a fitting end to his attempt to rob India's poor of their autonomy: "Something even more powerful, even more implacable, had finally defeated the ideology of population control: People voting, one by one" (p. 326).

The Bucharest Conference and the Indian Emergency serve as the climactic acts in the drama of the postwar population control movement. Over the next two decades, the old population establishment gradually fell apart under a dual assault from feminists and radicals on the left and resurgent pro-life conservatives on the right. Thus, even as women and men who "grew their hair long" took over key positions in family planning organizations and reoriented them to focus on reproductive rights rather than on population control, conservatives such as Senator Jesse Helms worked to end all U.S. aid for family planning programs overseas (p. 329). This, of course, makes perfect sense: the idea of population control, an important component of the Cold War, high modernist, developmentalist consensus, fell victim to the same combined attack from left and right that destroyed that consensus itself.

The story, however, does not end there. Even as the international family planning establishment was disintegrating, the People's Republic of China 
launched the largest and most coercive family planning program in history. The widespread Chinese abuses, which included forced abortions and sterilizations in strict enforcement of the one child policy, in turn provided opponents of family planning with further ammunition to dismantle USAID's population program in the Reagan era. For Connelly, the 1994 United Nation's Cairo program, which emphasized reproductive rights over reproductive control, marked the final "instrument of surrender" of the international population control movement (p. 369).

In his conclusion, Connelly, somewhat surprisingly given the critical tone that pervades much of the text, urges us to judge the population controllers with empathy and in the context of their time. They believed they were facing an unprecedented crisis in human history and saw themselves as promoting progress, fighting poverty, and saving the planet. Their great error, he argues, was the attempt to plan other people's families: “The great tragedy of population control, the fatal misconception, was to think one could know other people's interests better than they knew it themselves"' (p. 378). Citing studies that show that the education of women is the strongest correlate of lower fertility, Connelly concludes that ultimately it has been "the emancipation of women, not population control, that has remade humanity" (p. 375). It is a satisfyingly neat conclusion; perhaps a bit too neat, inasmuch as it elides some of the complexities involved, not least the tensions between interests individual and societal, short-term and long-term, and the longstanding debates over the place and meaning of women's emancipation in the global south.

Even readers who do not fully embrace Connelly's conclusions, however, will appreciate Fatal Misconceptions as a book that combines an original framework and challenging interpretations with an engrossing narrative replete with drama, surprising discoveries, and memorable turns of phrase. Connelly's reconstruction of the global population establishment is particularly compelling. Bringing to bear a broad range of sources-far-flung archives, obscure committee reports, press accounts- he manages to conjure an extensive, dynamic network that connected a diverse array of individuals and organizations, including government agencies, international organizations, and NGOs. This network, though firmly anchored in the West, had global reach. It was bound together by social, professional, and institutional ties, with ideas, discourses, funds, and people constantly circulating throughout. Connelly's methodology of research, framing, and narration in this book will be of special interest for those who seek, as Connelly does, to "see beyond the state" to other forces and institutions that have shaped the history of international society. ${ }^{2}$

The book is somewhat less convincing when it turns to more conventional ground, as when it advances the argument that the postwar population control movement was essentially imperialism by other means. In order to make the argument, Connelly defines imperialism as the "pursuit of unaccountable power," a definition so broad that readers may well doubt its usefulness. But 
even if one accepts "unaccountable power" as a sufficiently precise description of empire and concedes that this is what population controllers wanted to achieve, there remains the distinction between the "pursuit" of such power and its actual attainment. Though many members of the international population establishment held paternalistic, colonial attitudes toward the Third World poor-occasionally, Connelly shows, they were the same men who had previously served as colonial officials-they no longer held the ultimate power of decision. This now lay with postcolonial officials, and their apparent enthusiasm for family planning programs-which the book occasionally notes but does not much explore-was crucial in launching and sustaining those programs.

The book uncovers compelling connections between the international movement to control world population and the respective national programs, but it also makes it too easy to forget that the latter were more than simply components of the former. To varying degrees, the book shows, the major postwar family planning campaigns-in India, China, Indonesia, and elsewhere-got ideas, technical aid, and funds from international sources. But their primary goal, at least in the eyes of the national leaders who pursued them, was surely not to limit world population as such but to shape the size and character of the nation. In the early 1950s, as the international population establishment was just beginning to cohere, family planning was already a part of independent India's development plan, and in the mid-1970s, even as the international movement suffered its "Waterloo" in Bucharest, the Indian program was entering its most violent stage. And the largest, most coercive population control scheme of all, in the People's Republic of China, was conceived and launched with few international connections, indeed just as the international movement entered what Connelly describes as a stage of terminal decline.

It will fall to other scholars to explore more fully the roles and perceptions of non-Western actors in the history of population control and to delve more deeply into the interplay between national construction and global governance that this story suggests. Fatal Misconception remains a significant achievement that opens up new horizons for U.S. and international historians. It sheds new light on the role of the United States in world affairs, one that looks beyond both the agencies of the U.S. government and the tentacles of its cultural and commercial influences to show how private foundations and academic experts came together in an epic effort to reshape humanity on the most intimate and the grandest of scales at once. In the process, Connelly has demonstrated the importance and richness of historical work on non-state actors, including philanthropic foundations, NGOs, and international organizations for the novel perspectives that they offer on some of the most important and fascinating issues, methodological and substantive, before historians today. This book will stand as a pioneering effort and a challenging model in the burgeoning 
historiography now emerging at the intersections of transnational, international, and global history.

Erez Manela, Dunwalke Associate Professor of American History, Harvard University, is the author of The Wilsonian Moment: Self-Determination and the International Origins of Anticolonial Nationalism (2007) and is writing a history of the global campaign to eradicate smallpox.

1. Akira Iriye has made pioneering contributions to defining and conceptualizing this topic, for example Akira Iriye, Global Community: The Role of International Organizations in the Making of the Contemporary World (2002). Another important recent contribution is Amy L.S. Staples, The Birth of Development: How the World Bank, Food And Agriculture Organization, And World Health Organization Have Changed the World 1945-1965 (2006).

2. See Matthew Connelly, "Seeing Beyond the State: The Population Control Movement and the Problem of Sovereignty," Past \& Present 193 (2006): 197-233. The phrase, of course, echoes James C. Scott, Seeing Like a State: How Certain Schemes to Improve the Human Condition Have Failed (1998). 